\title{
Power, Arabism and Islam in the Writings of Muhib al-Din al-Khatib in al-Fath
}

\section{Amal N. Ghazal*}

ABSTRACT: The writings of Muhib al-Din al-Khatib reveal a deep concern over Muslim weakness in the face of European domination in the interwar period. In his weekly newspaper al-Fath, al-Khatib confronted the issues which threatened to increase Muslim division following the dissolution of the Ottoman Empire. He considered Islam the common bond by which all Muslims could unite to resist the West. While Arabism could fit into and uphold this unity, separatist nationalisms threatened it and caused further divisions inspired by the West. In his editorial writing, al-Khatib suggested various reforms aimed at reviving Muslim control of their own lands.

During the years of the interwar period, Europe reached the height of its dominion over Muslim lands, from West Africa to Indonesia. The same period marked the continuing rise of nationalities in the Muslim world, threatening its unity as one nation (Umma) and as a coherent body able to resist the European challenge. Alarmed by both dangers (European dominion and nationalities), many Muslim intellectuals became concerned with reuniting the Muslims to overcome their weakness, division, and vulnerability to the political and cultural influence of Europe. Arab Muslims were more concerned with the mingling identities of Islam and Arabism, and many conceived of them as complementary of and dependent upon each other. The prominent Islamist journalist Muhib al-Din alKhatib, troubled by the challenge from the West, tried to use the combination of Islam and Arabism to regenerate Muslim power. He explained their co-relation and tended more to show the dependency of Arabism on Islam. He concluded that Arab and Muslim solidarity could effectively intervene on 
behalf of vulnerable Muslims.

Al-Khatib was born in Damascus in July 1886, son of Abu al-Fath al-Khatib, a Damascene 'Alem.' He completed his secondary studies in Damascus and Beirut, where he used to meet Arab intellectuals such as Taher al-Jaza'iri, Fares alKhoury, Muhammad Kurd 'Ali, Rafiq al-'Azm, and 'Abd alRahman Shahbandar. ${ }^{2}$ In 1905, he went to study law in Istanbul where he again met "Aref al-Shihabi. Both of them were interested in meeting the Arabs there, and teaching them Arabic. After a while, he and 'Aref established the Society of Arab Awakening (Jam 'iyyat al-Nahda al-'Arabiyya). In 1907, he went to Cairo on his way to Yemen, where he met Rashid Rida, who had already established the Ottoman Council Society (Jam 'iyyat al-Shoura al- 'Uthmaniyya), which al-Khatib joined. After his two-year career in Yemen, he returned to Istanbul and suggested the establishment of a club for the Arabs, an idea fulfilled in 1909 by founding the Literary Club (al-Muntada al-Adabi). In 1913, the Decentralization Party (Hizb al-la Markaziyya) was established in Syria with al-Khatib as the assistant secretary, and the Arab Congress was held in Paris in which al-Khatib participated. One year later, he was asked by the Arab Union Society (Jam 'iyyat al-Jami 'a al-'Arabiyya) ${ }^{3}$ to go to Iraq and Najd. On his way, he was arrested in Bombay by the British and deported to Basra. After his release in July 1916, he went to Egypt, then to Mecca, where he met Sharif Hussayn. From 1916 to 1920, he edited al-Qibla, ${ }^{4}$ Sharif Hussayn's newspaper, and issued in November 1917 the weekly newspaper al-Irtiqa'. When he left for Damascus in 1919, he became a member in the central committee of the Arab Youth (al'Arabiyya al-Fatat), the editor of the official newspaper al'Asima, and he founded an educational center called alMa'had al-'Ilmi. With the collaboration of Shaykh Muhammad Kamel al-Kassab, he established, in September, ber, the High National Committee (al-Lajna al-Wataniyya $a l$-'Ulya) to provide Syria with arms and to train the Syrians 
for war. When troubles arose with King Faysal, al-Khatib left for Egypt where he spent the rest of his life. In 1921, he became the editor of al-Ahram for five years, and meanwhile established the Salafiyya Press. In 1934, he issued the magazine al-Zahra', and another weekly journal al-Fath in 1926 which appeared until 1948. He was also the editor of the Muslim Brothers' newspaper. ${ }^{5}$ In December 1969, al-Khatib died.

The following study of the Arab and Islamic thought of alKhatib is based on his articles written in al-Fath between 1927 and $1943 .^{6} \mathrm{Al}$-Fath, a weekly Islamic-oriented newspaper edited by al-Khatib himself, can be considered a pulpit for the dissemination of his political ideology, responding to events in the Muslim world. The importance of al-Fath relies on its being a major source for the study of al-Khatib's career after 1920 , a period not fully observed by the scholars who paid more attention to his political activities before the end of World War I. However, he seems not to be as active--politically-as he was before 1920, perhaps due to his association with the Muslim Youth Society (Jam 'iyyat al-Shubban alMuslimin) which had as one of its main principles a prohibition against interference in politics under any circumstances. ${ }^{7}$

\section{POWER: THE ULTIMATE NECESSITY}

The notion of power was basic for al-Khatib who frequently used the term 'power' (al-Quwwa) in his articles. He defined it as "the ornament of the world, the honour of people, the stimulus for their pride, and the determinant of their happiness." Power was also required as a matter of course since it was "the respectful virtue in the eyes of those who control the world." Addressing the Muslims, he asked them to be strong in their ethics, education, wealth and money, industry, trade, order, economics, and in any field of specialization. The source of this power was Islam, which bears in itself the seeds of strength since it "praises ethics, considers education 
a kind of worship, and recommends wealth and money."10 Yet power should not be read to imply military strength alone. While such strength was important, it was neither a priority nor, in itself, an underlying principle for al-Khatib. The vital principles were power of religion, ethics, education, knowledge, industry, organization, and innovation. " Al-Khatib's interest in generating power was enforced by the general mood that prevailed in the world at that time.

Most of these articles were written in the 1930s, when Fascism and Nazism had arisen, and when an arms race had been set in motion indicating that another World War was imminent. As his articles show, al-Khatib was impressed by the German leader Adolf Hitler. He symbolised for al-Khatib, as he did for many other Arab intellectuals and politicians at that time, a challenge to the unacceptable status quo (like the one Hitler saw imposed on Germany as a result of World War I), and the will for change and supremacy. Though the racism that characterized Hitler's speeches and program contradicts Islamic teachings, his influence on the Muslim Arabs may be explained by the appeal of his charismatic character and powerful rhetoric for the average Arab. Surprisingly enough, al-Khatib went much further by wishing that the Arabs and the Muslims were led by a person like Hitler: "A day will come when a leader similar to Hitler will unexpectedly appear to lead the Arab Bloc and the unity of Islam to that which no eye has ever seen, no ear has ever heard, and of which no Westerner has ever dreamt."12 The enmity of Germany to the occupying forces in most Arab countries - the French and the English — caused Hitler to be regarded as a saviour. In fact, what Germany achieved by the ability to recover from the unjust implementations of the Versailles Treaty was an ideal model which al-Khatib thought to apply to the Muslim world. 
"Unity in itself is power."'13 This was al-Khatib's underlying strategy. However, no Islamic unity would be possible unless the Arabs took a major part in it and unless the link between Islam and Arabism became clear and well defined. Reflecting the continued mixing of both identities after the World War I, al-Khatib tried to explain their close association and the impossible separation of Arabism from Islam on which it was dependent and to which it owed its glorious history.

Arab nationalism for al-Khatib did not rely on ethnic origins. Blood and racial relations among the Arabs were considered totally irrelevant compared to linguistic criteria. Since it was difficult to unite the Arabs on an ethnic basis, language became the common bond for unity. An Arab, as al-Khatib defined him, was "the one born in the Arab countries of Arabic-speaking parents."14 Lineage had been lost through civilization

which is a melting pot of a kinship solidarity that has no life but in the desert. The crucial point in a national civilized country is its language, culture, and common goal, and the countries that are united under one language and one culture, and subscribe to one common aim, form one nation. ${ }^{15}$

This Arab nation included Egypt, historical Syria (Bilad alSham), Iraq, Arabia, and North Africa. However, members originally from outside this geographical setting could also be included on the basis of their knowledge of Arabic language since the Arab "is not the one who lives in the desert - son of fathers of the tribe- but the Arab is the one who knows this language and participates in keeping its integrity."16 Historical figures such as Nur al-Din, ${ }^{17}$ Salah al-Din (Saladin), and alZamakhshari ${ }^{18}$ were regarded as belonging to the Arab nation; the first two by their political contribution, and the latter by his theological one. ${ }^{19}$ 
The incorporation of non-Arab elements into the category of the Arabs was not only applicable to those able to speak and write in Arabic, but also to those who were Muslim. Islam is intimately associated with the Arabs and their heritage, because Islam

transformed the tribal life into a state life; fanaticism based on kinship became fanaticism based on righteousness and welfare. And since Arabism was the key, organ, and translator of Islam, it spread with it. Thus, those who embraced Islam, spontaneously embraced Arabism. ${ }^{20}$

This direct and close connection of the Arabs to Islam provided them with a major role in history. The rise of Islam brought about the rise of the Arabs as a powerful nation with a mission to accomplish. The Arabs then became aware of their identity as preachers and protectors of the new religion. Without Islam, according to al-Khatib, the Arabs were worth nothing and could have never been able to reach high status among other nations: "Arabism and Islam are the same, their past is common and connected; moreover, what power is left for Arabism if it is deprived of Islam?"21 Thus, the star of the Arabs rose for being 'Muslim' Arabs and consequently the Arab nation "knows that it has no life except in Islam by which it gained ground throughout history."22

Another service Islam offered to the Arabs was that it united them. It "brought to the land inhabited by the Semitic people its linguistic and national union." ${ }^{.23}$ Therefore, Arabism is indebted to Islam for its initial unity mainly because the Arabic language was in the process of becoming corrupted when the Qur'an appeared and reunited it.

This close Arab-Islamic relationship was not only based on the political and military role of the Arabs in spreading Islam. It had grown much deeper and became a cultural relationship that had influenced Arab history. Al-Khatib could imagine any other culture deprived of a religious spirit, but he 
could not imagine the Arab culture deprived of the spirit of Islam. ${ }^{24}$ Thanks to Islam, the Arabs were able to "provoke the greatest advancement, the most merciful administration, the most just legislation, the happiest civilization, and the most beautiful architecture." ${ }^{25}$ In addition, it introduced the Arabs, through conquests, to Asian, African, and European civilizations.

To revive this glorious past, the Arabs should return to the teachings of Islam:

The Orient will not regain its power and life unless it goes back to the Muhammadian faith... and it's by Islam that the Orient will recover, regain its strength, and nurture in itself the mature ethics, and with it, it will be qualified to participate with the other nations in carrying the burden of civilization. ${ }^{26}$

This recourse to Islam was to be communal, summoning an Arab alliance of the Arab people "to protect the glory of their common nationality."27 An alliance would be necessary since the strength provided by common Arab origins had been divided and dispersed. When the Arabs become conscious of this hidden power, they would be able to carry out their duty as preachers and defenders of Islam:

The Arabic-speaking people should know themselves and then know their duty...this is our definition of how to revive Islam. Islam started as alien [ghariban; i.e., alien to Arabic society] and the Arabs embraced it during this first alienation [ghurbatuhu al-'ula], but now it has again become as alien as it was when it started. Therefore, the Arabs should go back to their duty that God has appointed them for." 28

Al-Khatib chose Palestine as a particular case of Muslim vulnerability, on behalf of which Arab and Muslim solidarity should intervene. He defined Palestine as "a Muslim Arab 
country which will remain as such,"29 and wrote that "each foot of ground in Palestine is a sacred Muslim place." ${ }^{\text {"In }}$ In his eyes, the question of Palestine was not a local affair, it wasor should have been - a matter of concern for all Arabs and Muslims.

Seventy million Arabic-speaking people, and three hundred million believers in the guidance of the prophet Muhammad, consider Palestine the gateway to the Two Holy Places, the heart of Arab nationalism, the heritage of Islamic history, and the country of eternal memories. ${ }^{31}$

Therefore, each Muslim should be committed to the Palestinian cause; otherwise,

a Muslim from any race who does not help the Palestinians to keep Palestine an Arab Islamic country should know that something wrong entered his relationship to the Islamic unity, and that this relationship thus needs treatment and reform. ${ }^{32}$

The German ideal for establishing a powerful nation reappeared in his position on the Palestinian issue. When he asked the Arabs not to buy Jewish products, he suggested the substitution of German ones..$^{33}$

Hence, Arabism relying on Islam would be able to generate power and revive its heroic past. Arab nationalism, as supported by al-Khatib, was set within a larger framework, that of Islam, presenting itself as the core of a far more ambitious project-Islamic union. Arab nationalism for al-Khatibin terms of interest and role- was not different from Islamic unity. Without a secular concept of Arab nationalism, he could only see it as a step to the fulfilment and achievement of Islamic consolidation. Its role was to back up Islamic interests world-wide, and thus any attempt to separate or isolate Arabism from Islam would result in overall failure, although 
Arab identity might be maintained and distinguished by the peculiarity of the Arabic language.

The weakness that characterized the Muslim world in general, and the Arab world in particular, demanded such a league in order to reproduce this lost power. The major cause of this weakness and humiliation of the Muslims, who "live individually like orphans deprived from the pleasure of gathering in a family under the two wings of fatherhood and motherhood,"34 was their neglect of Islamic teachings. Only by practising these teachings and following the guidance of Islam, would weakness be replaced by an Islamic power which was "very strong and evokes in followers motivation for a quick revival [of Islam] that can originate in miracles in any circumstances." 35

\section{AL-KHATIB'S ATTITUDE TOWARDS \\ EGYPTIAN NATIONALISM}

While Arab nationalism was highly praised and recommended by al-Khatib, Egyptian nationalism was blameworthy and reprehensible, ${ }^{36}$ since separatist nationalisms were regarded as a threat to the unity of the Arabs and the Muslims and a further weakness. Egyptian nationalism was, as he considered it, a political innovation created by the West and contradicting Islam. Islam determined that

the Islamic countries are one country for all Muslims, and the Muslim has to be a soldier for this greater country wherever he goes. This is the correct meaning of patriotism that has always been perceived throughout Islamic history, and any other meaning is a propaganda from the devil. . $^{37}$

Thus, Egyptian nationalism, which called for the non-interference of Egypt in external affairs (i.e., outside its geographical boundaries), and which considered Egypt an entity with no relation to the Arab world, did not correspond with the Arab 
and Islamic co-operation and union that al-Khatib envisioned.

Furthermore, the Egyptian nationalists' slogan, "Egypt for the Egyptians," was potentially harmful to a Syrian resident in Egypt such as al-Khatib. There was a press campaign directed against the Syrian community residing in Egypt. As a result, Egyptian nationalism did not only annoy al-Khatib theoretically, as a devout Muslim who believed that "believers are nothing but brothers," but also practically, as a Syrian living in Egypt yet unwelcome by some Egyptians. ${ }^{38}$ Despite his opposition to Egyptian nationalism, his love for Egypt, regardless of any religious character or national role, was exceptional. He chose to live in it and "I intend to die in its land-if God wills; I am a partner for every Egyptian in the patriotic union and it is the closest union to me because I am directly related to it, it benefits from my efforts, and I benefit from it by my achievements." 39 Nonetheless, he did believe that Egypt had a particular position and an indispensable importance in the Arab and the Muslim world. ${ }^{40}$ Egypt's location is central among all Arab and Muslim countries:

Egypt alone-being a mid-point between the Arabs of Western Asia and those of North Africa, being the largest of Arab countries in its population, being the transmitter of Islamic and modern cultures, being the centre of publishing and the broadcasting in all Arab lands-should hold the banner of unity in its hands, and thus its profit is greater than that of any other Arab country. ${ }^{41}$

In addition, Egypt, "the lovely country of the Egyptian, is the Nile Valley, but it is a small territory for a very ambitious nation."42 Such ambition necessitated a leadership role if it was to overcome the inadequacy of agricultural land, to support its growing population, by expansion-an expansion welcomed in the hearts, houses and markets of neighbouring nations. ${ }^{43}$

Al-Khatib refused a separatist Egyptian nationalism which set itself outside the Arab and Muslim world. Thus, Egypt 
Al-Khatib refused a separatist Egyptian nationalism which set itself outside the Arab and Muslim world. Thus, Egypt seemed to have been more important for al-Khatib than for the Egyptian nationalists themselves. If they - the Egyptian nationalists - were hoping to serve Egypt's interest by excluding it from its natural associates, al-Khatib was looking forward to a role by which Egypt would lead the Arab and the Muslim countries.

THE WEST: A THREAT TO ISLAM AND ISLAMIC UNITY

Al-Khatib was stirred up by the process of Westernization that Egypt was following and adopting. The influence of Western ideas was apparent to him in the spread of alcohol and drugs and in the moral corruption that he felt characterized Egyptian youth. Moreover, Al-Khatib believed that all separatist nationalisms were inspired by the conspiring West to divide the Muslims:

$\mathrm{He}$ (the Westerner) comes to the Turk and tells him: 'Do you see this prayer that your mother performs at home? It is an Arab prayer. The Turkish nationality is oppressed by the Arab one. The reading of the Qur'an by the Turks is in Arabic, their performance of prayer is also in Arabic, and their esteem to the great men of the Arabs, from the Companions to the Followers, is nothing but Arab colonization of your nationality'... then he comes to the educated Egyptian and says: 'What do you have to do with the Arabs, their history; and their glory? Look at the remnants of the Pharaohs, look at the history of the old Egyptians! ${ }^{44}$

Who exactly represents this West was not indicated by alKhatib. However, in his discussion of the Palestinian cause, he often referred to the Jews as the main cause of the corruption, not only in the Muslim countries, but also in the whole 
organizing. "The Jewish finger established the Masonic order, drew the Bolshevik program, and wrote the law of the Committee of Union and Progress." 45 By supporting these movements, the Jews intended to "throw the seeds of division and disunity in each country."46 Even the rejection of the veil in the Muslim world was a result of the Jewish call for emancipation. It was a tool to carry out the Zionist plan which aimed "to lead our women, and us, to believe in following a path other than that of decency." 47

Emancipation and social problems caused by the Jews pointed, according to al-Khatib, to a plot to destroy nationalities, and religious, moral, and economic elements so that "the Israelis will remain the only powerful people on earth."48 For example, the presence of the Jews in Palestine was regarded by him as a threat not only to the Palestinians, but also to the entire Orient because the Jews took Palestine as a social base "to conquer all the Arab Orient-Syria, Iraq, and Egypt-and to shackle its inhabitants to their economic network, and entice them with different colours and shapes of moral and social drugs." 49

\section{SOME SUGGESTED REFORMS}

Unity could not be achieved unless some reforms would be included to empower it. Al-Khatib admitted the unfavourable conditions of the Arab world and looked for ways of improvement. Thus, political and educational reforms were required to achieve Arab and Muslim leadership. Reforms also reached the doctrinal level. Since he was incorporated in the Salafiyya movement led by his friend Rashid Rida, he supported the idea that Islam is a religion of "doctrine, worship, and nule," 50 not only restricted to ritual performance because "its virtues without its doctrines are incomplete, its religious observances denuded of its virtues curse the performer, and its doctrines denuded of its rules remain sick until these rules are established and then, its doctrines survive." ${ }^{\text {11 }} \mathrm{He}$ also con- 
its doctrines denuded of its rules remain sick until these rules are established and then, its doctrines survive." 51 He also considered religious innovations (bida ${ }^{\circ}$ ) as obstacles in the way of revival and creativity. Therefore, Islam must be freed of the "heretical innovations that were introduced to it...and these reforms will spread a spirit of activity among the Muslims." 52

At the educational level, al-Khatib argued Islamic education should not be restricted to religious education consisting of judgements and morals, but it should be comprehensive bringing up the Muslim youth "loving Islam, eager in its pursuit, fighting for its sake, and standing with humble, holiness and splendour for the memory of its great men and heroes." 53 The educational program should include, beside mathematics, engineering, and other scientific fields, "the material related to nationalism and its birth, and the relation between its future and the circles of its past, with history being the most important element of this material."s4

Knowledge of history would be essential for national education and for the awakening of the Arab nation because "history is the belief that the present of the Arabic-speaking countries is the son of their near past of the last fourteen centuries, and that their future has to be built upon this present and upon the near past." 55 Moreover, history was a major element in national education for all nations that "enjoy the blessing of power and the blossoming of life." ${ }^{.56}$ All other nations knew how to learn and benefit from their past except the Arabs "who use neither the pre-Islamic nor the post-Islamic history to form their national identity that helps us in the struggle of the nations and the fight of nationalities." ${ }^{57}$ Despite the brilliant history of the Arabs and the Muslims, it still needed "a builder who reconstructs it in order to appear splendid, brilliant, magnificent, and illuminating; and then, our glories will receive their share of beauty in the eyes of both our sons and our enemies." $" 58$

Al-Khatib's economic reforms also aimed at strengthening unity through such means as the removal of taxation barri- 
and encourage industry in the Islamic Orient in general. ${ }^{\text {"59 }}$ At the political level, he argued for an Arab/Islamic Intelligence Bureau to watch the events in the Orient and the reaction to them in the Western press. The mother-bureau should be, according to al-Khatib, in Cairo, where the youth "should be trained to observe the Eastern and the Western press and their attitude towards the Muslims, organize information, and publish it in a way to present a good image of Islam and the Muslims."60

Though it is difficult to claim that al-Khatib had a specific consistent reform program, those suggestions reflected the need of fundamental reforms in the Muslim society on one hand and the awareness of the Muslims' weak position vis-àvis the West on the other. His recommendations would reinforce the awareness and unity of the Muslims and would put them forward in their encounter with the West.

All these issues raised and discussed by al-Khatib in his weekly newspaper al-Fath reflected the attitude of an Arab Muslim intellectual towards the political and social situation prevailing in the Muslim world during the interwar period. He witnessed the last days of the Ottoman order, the European expansion in and occupation of Muslim territories, and the rise of both Arab nationalism and pan-Islamism. His main concern was to find a way to unite the Muslims, of whose division and vulnerability he was fully aware. To solve the dilemma between Arabism and Islam, he clarified their link to each other and explained the dependency and indebtedness of the first to the latter. In any case, the urgency of the Muslim reunion had become essential, especially after the appearance of the Palestine question which heightened the need of Arab and Islamic solidarity. Moreover, the Western cultural impact on Arab and Muslim behaviour urged the search for lost identity and the missing role necessary to meet the Western cultural challenge. However, nothing could be successfully done unless serious reforms were conducted at the doctrinal, political, and educational levels. The ideal for Muhib al- 
fully done unless serious reforms were conducted at the doctrinal, political, and educational levels. The ideal for Muhib alDin al-Khatib, as for many others, was to rely on the heroic historical role of the Arabs, and to utilize the large Islamic territory and population of Islam in order to generate and mobilize the greatest possible support.

\section{NOTES}

"I would like to thank Dr. Samir Seikaly, chairman of the History Department at the American University of Beirut, for his continuous support during the five years I spent under his supervision. This article would not have been written had not he suggested its topic. I would also like to thank the two anonymous referees whose valuable comments on the manuscript were more than helpful.

${ }^{1}$ A Muslim religious scholar.

${ }^{2}$ These were the members of the 'Senior Circle' of the Arab intellectuals in Damascus while Muhib al-Din al-Khatib, Lutfi al-Haffar, Saleh Qanbaz, 'Aref al-Shihabi, and 'Uthman Mardam Bek were the members of the 'Junior Circle'. They all attended Maktab 'Anbar, the only high secondary school in Syria at that time. See David D. Commins, Islamic Reform: Politics and Social Change in Late Ottoman Syria (New York: Oxford University Press, 1990), 92-98. For more details on Maktab 'Anbar, see Zafer al-Qasimi, Maktab 'Anbar (Beirut: al-Matba'a al-Kathulikiyya, 1963). The introduction of this book is repeated in 'Ali al-Tantawi, Dimashq: Suwar min jamaliha wa 'ibar min nidaliha, 2nd ed. (Damascus: Dar al-Fikr, 1987).

${ }^{3} \mathrm{Al}-\mathrm{Kh}$ atib played a major role in the establishment and direction of the early Arab societies and committees. See Muhammad 'Abd alRahman Burj, Muhib al-Din al-Khatib wa dawrahu fi al-haraka al'arabiyya, 1906-1920 (Cairo: al-hay'a al-masriyya al-'amma lil-kitab, 1990), and Suhayla al-Rimawi, "Safahat min tarikh al-jam "iyyat fi bilad al-Sham: min al-jam "iyyat al-'ilmiyya ila al-jam 'iyyat al-siyasiyya," Dirasat Tarikhiyya 7 (January 1982): 134-156.

${ }^{4}$ It was published in Mecca from 1916 to 1924. It is a major source on Arab attitude during the WWI years, and can be considered, as William Cleveland mentioned, "the organ of the Arab revolt and the most important forum for the justification of the revolt to Arab society." See W. L. Cleveland, "The Role of Islam as Political Ideology in the First World War,' in National and International Politics in the Mid- 
al-Rimawi, "Janeb min fa aliyyat Muhib al-Din al-Khatib: al-janeb alsahafi," Dirasat Tarikhiyya 23-24 (1989): 23-48.

${ }^{6}$ As mentioned above, al-Fath appeared until 1948, but the volumes covering the years between 1944 and 1948 (except 1947) are missing in Jafet Library at the American University of Beirut, where this study was conducted. Translations are by the author.

7 J. Dunne-Heyworth, Religious and Political Trends in Modern Egypt (Washington, 1950), 11. Al-Khatib was one of the founders of the Society in 1927.

${ }^{8}$ Al-Fath 14 (1941): 492.

${ }^{9}$ Al-Fath 13 (1940): 540.

${ }^{10} \mathrm{Ibid}$.

${ }^{11}$ Al-Fath 14 (1941): 492.

${ }^{12}$ Al-Fath 13 (1940): 588.

${ }^{13}$ Ibid., 540.

${ }^{14}$ Al-Fath 9(1934): 806.

${ }^{15}$ Al-Fath 8 (1933): 230.

${ }^{16}$ Al-Fath 7 (1932): 129.

${ }^{17}$ Nur al-din Mahmud ibn Zanki, a Zankid sultan who fought the crusaders during the twelfth century.

${ }^{18}$ Abu al-Kasim Mahmud ibn Umar (1075-1144), a Persian-born Arabic scholar, philologist and theologian.

${ }^{19}$ Al-Fath 7 (1932): 129.

${ }^{20}$ Al-Fath 18(1947): 179.

${ }^{21}$ Al-Fath 14(1939): 380.

${ }^{22}$ Al-Fath 11 (1936): 728.

${ }^{23}$ Ibid.

${ }^{24}$ Al-Fath 14 (1939): 380.

${ }^{25}$ Al-Fath 11 (1936): 728.

${ }^{26}$ Al-Fath 8 (1933): 445

.${ }^{27}$ Al-Fath 13 (1938): 187.

${ }^{28}$ Al-Fath 7(1932): 130.

${ }^{29}$ Al-Fath 6(1933): 306.

${ }^{30}$ Al-Fath 11 (1936): 127.

${ }^{31}$ Al-Fath 8(1935): 366.

${ }^{32}$ Ibid., 205.

${ }^{33}$ Al-Fath 11 (1938): 464.

${ }^{34}$ Al-Fath 6(1933): 193.

${ }^{35}$ Al-Fath 5(1932): 370.

${ }^{36} \mathrm{He}$ had a similar attitude towards Syrian nationalism. See, for instance, Nimrod Huritz, "Muhibb ad-Din al-Khatib's Semitic Wave Theory and Pan Arabism," Middle Eastern Studies 29 (7) (1993): 118- 
stance, Nimrod Huritz, "Muhibb ad-Din al-Khatib's Semitic Wave Theory and Pan Arabism," Middle Eastern Studies 29 (7) (1993): 118134.

${ }^{37}$ Al-Fath 2(1928): 787.

${ }^{38}$ For more elaboration on this point, see Israel Gershoni and James P. Jankowski, Egypt, Islam and the Arabs: The Search for Egyptian Nationhood, 1900-1930 (Oxford: Oxford University Press, 1986). ${ }^{39}$ Al-Fath 9 (1936): 806.

${ }^{40}$ Gershoni elaborated on this point in Israel Gershoni, "Arabization of Islam: The Egyptian Salafiyya and the Rise of Arabism in Pre-Revolutionary Egypt," Asian and African Studies 13 (1) (1979): 51-53.

${ }^{41}$ Al-Fath 10 (1937): 855.

${ }^{42}$ Al-Fath 8(1935): 230.

${ }^{43}$ Al-Fath 10 (1937): 856.

${ }^{44}$ Ibid., 786.

${ }^{45}$ Al-Fath 3 (1929): 257.

${ }^{46}$ Tbid.

${ }^{47}$ Ibid., 258.

${ }^{48}$ Al-Fath 11 (1938): 464.

${ }^{49}$ Ibid.

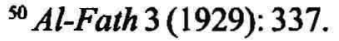

${ }^{51}$ Al-Fath 18(1947): 251.

${ }^{52}$ Al-Fath 10 (1937): 81.

${ }^{53}$ Al-Fath 8 (1935): 748.

${ }^{54}$ Al-Fath 12 (1939): 1088.

${ }^{55}$ Ibid.

${ }^{56}$ Ibid., 272.

${ }^{57}$ Tbid.

${ }^{58}$ Al-Fath 9 (1936): 759.

${ }^{59}$ Ibid., 135.

${ }^{60}$ Al-Fath 2 (1928): 738. 